\title{
Ammatillinen koulutus - taitoa ja käytäntöä
}

\author{
Susanna Tauriainen \\ Ammatillisen koulutuksen linja, Opetushallitus, PL 380 (Hakaniemenkatu 2), 00531 Helsinki
}

Ammatillinen peruskoulutus rakentuu peruskoulun oppimäärälle, jonka käytännössä lähes jokainen suorittaa. Peruskoulunsa päättäneistä lähes $95 \%$ jatkaa opintojaan joko (upper secondary) yleissivistävässä lukiossa taikka ammatillisessa peruskoulutuksessa, jotka ovat rinnakkaisia koulumuotoja.

Ammatillista peruskoulutusta on tarjolla kaikilla elinkeinoelämän aloilla. Koulutus on kauttaaltaan kolmivuotista sisältäen noin puolen vuoden verran työpaikoilla tapahtuvaa työssäoppimista. Tutkinnot tuottavat yleisen jatko-opintokelpoisuuden korkeakouluihin ja yliopistoihin. Luonteva jatko-opintoväylä ammatillisen peruskoulutuksen suorittaneilla ovat ammattikorkeakoulut, joiden aloittaneista vajaa kolmannes on ammatillisen peruskoulutuksen suorittaneita. Yliopistoihin mennään nykyisin lähes kokonaan lukion kautta, mutta ammatillinen väylä on myös mahdollinen.

Nuoret hankkivat ammatillisen peruskoulutuksensa pääasiassa oppilaitoksissa opiskellen ja yhdistämällä siihen työpaikalla tapahtuvaa opiskelua. Oppisopimuskoulutus tarjoaa vaihtoehtoisen ja käytännönläheisen tavan hankkia ammatillinen perustutkinto. Oppisopimuskoulutuksessa työpaikalla tapahtuvan opiskelun osuus on noin $80 \%$ koulutusajasta.

Ammatillisen perustutkinnon voi suorittaa joko ammatillisissa oppilaitoksissa opetussuunnitelmaperusteisesti opiskellen tai näyttötutkintoina, jotka on suunniteltu erityisesti aikuisia ja työkokemusta hankkineita varten. Ammattitaitovaatimukset ovat suorittamistavasta riippumatta samat.

Ammatti- ja erikoisammattitutkinnot ovat pääasiassa aikuiskoulutusta. Ne täydentävät ammatillista peruskoulutusta ja antavat mahdollisuuksia erikoistumiseen kapeillekin työelämän alueille.

Opetussuunnitelman perusteet määrittelevät ammattitaitovaatimukset, opintojen tavoitteet osaamisena sekä keskeiset sisällöt. Opinnot koostuvat erilaisista ammatillisista opinnoista, yhteisistä opinnoista sekä vapaasti valittavista opinnoista.

\section{Opintojen koostumus}

Ammatilliset opinnot 90 ov laaja-alaiset perusopinnot erikoistavat opinnot työssäoppiminen Yhteiset opinnot 20 ov Vapaasti valittavat opinnot $\quad 10 \mathrm{ov}$ 
Ammatillisten opintojen koostumus riippuu alasta ja tutkinnosta. Tutkinnossa on ammatillisia perusopintoja, joiden laajuus vaihtelee (tavallisin vaihteluväli 30-40 opintoviikkoa. Koulutusohjelmien mukaisia erikoistumisopintoja on tavallisesti 40-60 opintoviikon verran. Sen lisäksi on muita valinnaisia opintoja, joissa voi erikoistua. Ammatilliset opinnot on muodostettu työelämän toimintakokonaisuuksien pohjalle rakentuviksi opintokokonaisuuksiksi. Ne toimivat arvioinnin ja näyttöjen pohjana. Arvosanat annetaan opintokokonaisuuksista ja ne näkyvät todistuksissa. Tutkintoon kuuluu opinnäytetyö (laajuus 2 ov). Ammattiosaamisen näytöt otetaan käyttöön syksyllä 2006 alkavassa koulutuksessa.

Kaikkiin ammatillisen peruskoulutuksen tutkintoihin sisältyy vähintään 20 opintoviikkoa työssäoppimista. Sillä tarkoitetaan työpaikoilla aidoissa työympäristöissä tapahtuvaa opetussuunnitelman mukaista opiskelua. Työssäoppimispaikan järjestämisestä vastaa koulutuksen järjestäjä, joka tekee työpaikan edustajan kanssa kirjallisen sopimuksen. Yleensä opiskelija ei ole työsuhteessa, vaan säilyttää opiskelijan statuksen ja opintososiaaliset etunsa. Työnantajille ei myöskään yleensä makseta korvauksia. Työssäoppimispaikka voi olla ulkomaillakin, kunhan ohjauksesta on voitu sopia.

Luonnonvara- ja ympäristöalan koulutusalaan kuuluvat seuraavat perustutkinnot ja niiden koulutusohjelmat:

Maatilatalous

Maatalousalan perustutkinto

Hevostalouden koulutusohjelma, hevostenhoitaja, ratsastuksenohjaaja

Maatilatalouden koulutusohjelma, maaseutuyrittäjä

Turkistuotannon koulutusohjelma, turkistarhaaja

Puutarhatalous

Puutarhatalouden perustutkinto, puutarhuri

Kukka- ja puutarhakaupan koulutusohjelma

Puutarhatuotannon koulutusohjelma

Viheralan koulutusohjelma

Kalatalous

Kalatalouden perustutkinto

Kalatalouden koulutusohjelma, kalanjalostaja, kalanviljelijä, kalastaja, kalastuksenohjaaja

Metsätalous

Bioenergia-alan perustutkinto (kokeilu)

Turve-energian tuotannon ja logistiikan koulutusohjelma (kokeilu)

Peltoenergian tuotannon ja logistiikan koulutusohjelma (kokeilu)

Puuenergian tuotannon ja logistiikan koulutusohjelma (kokeilu)

Metsäalan perustutkinto

Metsätalouden koulutusohjelma, metsuri

Metsäkonealan koulutusohjelma, metsäkoneenkuljettaja

Metsien monikäytön koulutusohjelma, metsäluonnonhoitaja

Luonto- ja ympäristöala

Luonto- ja ympäristöalan perustutkinto

Ympäristöalan koulutusohjelma, ympäristönhoitaja

Luontoalan koulutusohjelma, luontoyrittäjä

Poro- ja luontaistalouden koulutusohjelma, porotalousyrittäjä, luontaistalousyrittäjä 
Vuonna 2004 toisen asteen luonnonvara- ja ympäristöalan koulutusta tarjotaan 43 oppilaitoksessa, joilla on toimipisteitä yhteensä 64. Eri perustutkintoja tarjoavien opetuspisteiden määrän kehitys näkyy taulukosta 1. Lisäksi luonnonvara- ja ympäristöalan perustutkintotasoista koulutusta järjestävät muutamat aikuiskoulutuskeskukset.

Suomenkielisistä ammattikorkeakouluista 7 tarjoaa maaseutuelinkeinojen koulutusohjelmaa, 7 metsätalouden koulutusohjelmaa, 3 metsä- ja puutalouden markkinoinnin koulutusohjelmaa, 2 kestävän kehityksen koulutusohjelmaa, 2 puutarhatalouden koulutusohjelmaa ja yksi hevostalouden koulutusohjelmaa. Ruotsinkielisessä ammattikorkeakoulussa on tarjolla maaseutuelinkeinojen, puutarhatalouden, kestävän kehityksen, maisemansuunnittelun ja metsätalouden koulutusohjelmat.

Taulukko 1. Luonnonvara- ja ympäristöalan oppilaitosten opetuspisteiden määrä ja opiskelijamäärä

\begin{tabular}{|l|l|l|l|l|}
\hline Opintoala & \multicolumn{2}{l|}{ Opetuspisteitä/kpl } & \multicolumn{2}{l|}{$\begin{array}{l}\text { Opiskelijoita } \\
\text { keskimäärin }\end{array}$} \\
\hline & 1995 & 2002 & 1995 & 2002 \\
\hline Maatilatalous & 43 & 40 & 56 & 84 \\
\hline Puutarhatalous & 16 & 19 & 101 & 100 \\
\hline Kalatalous & 4 & 4 & 70 & 45 \\
\hline Metsätalous & 29 & 28 & 57 & 66 \\
\hline Muu luonnonvara-ala & 1 & 27 & 27 & 25 \\
\hline & & & & \\
\hline Luonnonvara-ala yhteensä & 78 & 71 & 76 & 108 \\
\hline+ erityisoppilaitoksia & 2 & 5 & & \\
\hline
\end{tabular}

Lähde: Tilastokeskus, Opetushallituksen tietojärjestelmä OPTI

Vuonna 2004 maatalousalan perustutkintoa on tarjolla 30 oppilaitoksessa, joilla on toimipisteitä 33. Puutarha-alan perustutkintoon johtavaa ja/tai näyttötutkintoihin valmistavaa koulutusta antaa 18 oppilaitosta. Muuta luonnonvara-alaa edustavan luonto- ja ympäristöalan perustutkinnon voi suorittaa 23 oppilaitoksessa. Koulutuksen järjestäjien lukumäärä on viime vuosina pienentynyt, mutta toimipisteiden lukumäärässä ei ole tapahtunut merkittäviä muutoksia.

Toisen asteen maatilatalouden koulutuksessa kokeillaan myös uusia koulutusohjelmia. Nämä kokeilut nousevat työelämän tarpeista. Vasta vuoden on voinut valita maatalousteknologian koulutusohjelman, joka nimensä mukaisesti on teknologiapainotteinen. Koulutusohjelma vastaa yhä lisääntyvään tilojen töiden ulkoistamistarpeeseen antaen valmiuksia koneurakointiin, koneiden huolto-, palvelu- ja alihankintatoimintaan.

Toinen uusi koulutusohjelma on eläintenhoidon koulutusohjelma, josta valmistuu eläintenhoitajan ammattiin. Koulutuksen aikana voi suuntautua joko pelkästään pieneläinten tai tuotantoeläinten hoitoon. Myös molempia näistä voi opiskella kiinnostuksensa mukaan. Tämä koulutusohjelma on ollut erityisen suosittu, eikä kaikki halukkaat ole onnistuneet saamaan opiskelupaikkaa. Eläintenhoitaja työskentelee esimerkiksi lomittajana, pieneläinkaupan palveluksessa tai itsenäisenä yrittäjänä, eläinlääkäreiden avustajina klinikoilla tai eläinhoitoloissa.

Maatalousalan opinahjojen yhteydessä ylläpidetään opetusmaatiloja, joissa moni nuori saa ensimmäisen kosketuksen käytännön työelämään. Ne ovat ensiarvoisen tärkeitä oppimisympäristöjä nuorille saada tilaisuus kokeilla ja harjoitella työtehtäviä tulevaa ammattia varten. Usein opetusmaatiloilla myös varmistetaan riittävä osaaminen ennen kuin opiskelija lähetetään koulun ulkopuolelle työelämään työssäoppimispaikalle.

Tällä hetkellä on monen opetusmaatilan toimintaa uudistettu ja kehitetty. Laitekantaa on uusittu ja tuotantomuodoissa on haettu erikoistumista. Opetusmaatila on joissakin oppilaitok- 
sissa myyty joko kokonaan tai osittain ulkopuoliselle yrittäjälle. Myös erilaisia yhteistyösopimuksia koulun lähialueen maatilojen kanssa on solmittu, jotta oppilaat voivat opiskella mahdollisimman monipuolisesti eri tuotantosuuntia. Osa opetusmaatiloista on katsonut parhaakseen säilyttää itse mahdollisimman monipuoliset opetus- ja havaintotilat niin, että tilalta löytyy monia eläinlajeja ja -kasveja. Siltikin liian moni oppilaitoksista on keskittynyt vain lypsylehmien tuotantoon, sillä esimerkiksi siipikarjanhoitoon erikoistunutta opetusmaatilaa ei tällä hetkellä löydy yhdestäkään maatalousalan oppilaitoksesta. Siipikarjan lihan kulutuksen lisääntyessä soisi lintuja näkyvän yhä enemmän myös opetusmaatiloilla, jotta alan vaatima erikoiskoulutus tulisi vahvemmin turvattua.

Koko ammatillisen toisen asteen koulutusta uudistetaan parhaillaan. Tammikuun alusta on tullut voimaan laki ammattiosaamisen näytöistä, jonka mukaan opiskelijat näyttävät osaamistaan tekemällä tulevan ammattinsa työtehtäviä. Toisin sanoen maaseutuyrittäjän tutkintoa opiskeleva opiskelija muokkaa maata, kylvää, korjaa satoa, ruokkii ja hoitaa eläimiä tai tekee EU:n vaatimaa dokumentointia. Opiskelija näyttää siis osaamistaan niissä työtehtävissä, mitä hänen opiskelemassa ammatissakin vaaditaan. Näytöt ovat osa opiskelijan arviointia niin, että ne korvaavat osan vanhoista koepaperisuorituksista.

Opiskelijan tulee antaa näyttö osaamisestaan kaikissa ammatillisissa opinnoissa, joita tutkinnossa on 90 opintoviikkoa. Näytöt kattavat siis suurimman osan tutkinnon arviointitavoista. Opiskelua viedään heti alkumetreiltä lähtien käytännön suuntaan. Tämän uudistuksen toivotaan motivoivan ja innostavan opiskelijoita erityisesti maatalouden alalla, jossa nuorten opiskelun keskeyttäminen on keskimääräistä yleisempää ja vakava ongelma.

Näyttö voidaan tehdä joko opetusmaatilalla, mutta yleisimmin työssäoppimistiloilla ympäri maata. Oppilaitoksen yhteistyö alueen maatilojen kanssa on erityisen tärkeää, jotta nuori saa mahdollisimman todenmukaisen kuvan nykyajan maaseutuyrittäjän työstä. Opiskelijat tulevat työssäoppimisjaksolle tekemään tilan toimintaan kuuluvia töitä yhdessä tilanväen kanssa. Tilalla opiskelija saa palkaksi ohjausta ja tukea ennalta sovittujen tavoitteiden saavuttamiseksi. Työssäoppiminen on osa opiskelua, joten siitä ei makseta erillistä korvausta. Opettaja hoitaa pääosin vaadittavan kirjanpidon ja tulee seuraamaan jonakin sovittuna työpäivänä näyttöä. Sitä ennen opiskelija on saattanut harjoitella opintojaksoon kuuluvien töiden tekemistä jo viikon tai pari. Yhdessä tilanväen, opettajan ja oppilaan kanssa keskustellaan näytön onnistumisesta. Työpaikkaohjaaja ja /tai opettaja päättävät arvioinnista. 